\title{
Nytt verktøy for å oppdage delirium og kognitiv svikt
}

\author{
Delirium er et vanlig ledsagerfenomen ved akutt sykdom hos eldre pasienter. Tilstanden kan likevel være \\ vanskelig å diagnostisere. 4AT er et nytt screeningverktøy som nå er oversatt til norsk, og som kan bidra til \\ at flere pasienter med delirium får korrekt diagnose.
}

Delirium rammer $30-50 \%$ av alle eldre innlagt i sykehus og enda flere i intensivavdelinger (1). Diagnosekriteriene legger vekt på at delirium er en akutt innsettende forstyrrelse i kognisjon, bevissthet og oppmerksomhet som skal ha en utløsende årsak, og som ikke kan forklares av en kjent demenstilstand. Et annet viktig kjennetegn er at tilstanden ofte fluktuerer (2).

Det er vesentlig å diagnostisere delirium da den utløsende årsaken kan representere akutt, alvorlig sykdom. Prognosen ved delirium er alvorlig. Det er veldokumentert at pasienter som gjennomgår delirium har økt risiko for både død, demensutvikling og institusjonalisering (3).

Noen ganger er det åpenbart at pasienten har delirium, men i andre tilfeller er diagnosen vanskelig å stille. Pasienter med delirium kan presentere hyperaktive symptomer som stor uro, vandring og hvileløshet, ikke sjelden også psykiatriske symptomer som hallusinasjoner og vrangforestillinger. Disse pasientene er ofte lette å identifisere. Hos andre pasienter dominerer hypoaktive symptomer som døsighet, lavt psykomotorisk tempo og redusert oppmerksomhet mot omgivelsene. Slike pasienter er vanskeligere å gjenkjenne og har antakelig mer alvorlig prognose (4).

Screeningverktøyet 4AT er utviklet i Storbritannia og er en forkortelse for «4 A's test». Testen er konstruert slik at pasienter med både hypoaktivt og hyperaktivt delirium fanges opp.

\section{Fire deltester}

4AT er bygd opp slik at en skår på null poeng tilsier at delirium eller bakenforliggende kognitiv svikt er usannsynlig. En totalskår over fire skal først og fremst vekke mistanke om delirium, mens skår mellom ett og tre poeng kan indikere både delirium og underliggende kognitiv svikt.

I første delspørsmål skal undersøkeren ta stilling til om pasienten er alminnelig oppmerksom mot omgivelsene. Dersom pasienten er alminnelig oppmerksom, skåres dette som null poeng. Pasienten skårer også null poeng dersom vedkommende er døsig inntil ti sekunder etter oppvåkning for så å te seg normalt. Alt annet enn dette skal skåres som fire poeng. Dette understreker at enhver redusert oppmerksomhet mot omgivelsene skal vekke mistanke om delirium.

Delspørsmål to består av fire orienteringsspørsmål der pasienten skal oppgi fødselsdato, alder, årstall og navnet på det aktuelle sykehus. Har pasienten alt rett, skårer vedkommende null poeng. Ved en eller flere feil skårer pasienten henholdsvis ett eller to poeng.

Det tredje delspørsmålet går ut på at pasienten skal nevne årets måneder baklengs. Dersom pasienten uten feil kommer til juni eller lengre, skåres null poeng, og dersom vedkommende ikke kommer til

\section{«Endring i oppmerk- somhet og bevissthet \\ er kjernesymptomer ved delirium»}

juni uten feil, skåres ett poeng. Dersom pasienten ikke klarer å starte testen, skåres to poeng, noe som igjen understreker at endring $\mathrm{i}$ oppmerksomhet og bevissthet er kjernesymptomer ved delirium.

I delspørsmål fire skal undersøkeren ta stilling til om det er holdepunkter for at det aktuelle hadde akutt start eller har hatt et svingende forløp. Her må undersøkeren lene seg på opplysninger fra pårørende, journal og pleiepersonell. Ved holdepunkter for akutt start og/eller svingende forløp skåres fire poeng, ellers skåres null poeng.

\section{Endret bevissthet og fluktuasjoner}

$\mathrm{Vi}$ mener at verktøyet 4AT representerer et stort fremskritt innen deliriumdiagnostikk da testen kan utføres av alle typer helsepersonell, ikke krever spesifikk opplæring, er rask å gjennomføre og understreker at enhver oppmerksomhetssvikt skal vekke mistanke om delirium. Dersom pasienten ikke forholder seg normalt til undersøkeren, skåres dette med fire poeng, og pasienten er umiddelbart i kategorien «delirium sannsynlig.»

På samme måte skåres akutt debut og/ eller svingende forløp med fire poeng. Dette understreker viktigheten av komparentopplysninger og peker også på at svingende forløp er nærmest patognomonisk for delirium. En skåre på ett til tre poeng kan oppnås dersom pasienten er desorientert eller ikke klarer å nevne årets måneder baklengs. En slik skåre utelukker ikke delirium, men dersom pasienten er alminnelig oppmerksom i samtalen, og det ikke er holde- punkter for akutt start og svingende forløp, er underliggende kognitiv svikt vel så sannsynlig som delirium.

Screeningverktøyet 4AT er utviklet i Storbritannia (5) og allerede oversatt til, og validert på, italiensk (6). Vi har oversatt 4AT til norsk, og oversettelsen er nå tilgjengelig på hjemmesidene til Norsk geriatrisk forening (7). Vi planlegger også en norsk valideringsstudie.

Artikkelforfatterne utgjør arbeidsgruppen for
norsk oversettelse og validering av 4AT.

Sigurd Evensen

sigurd.evensen@ntnu.no

Thea Forr

Ahmad Al-Fattal

Cathrine de Groot

Greger Lønne

Edith Roth Gjevjon

Geir V. Berg

Sverre Bergh

Sigurd Evensen (f. 1979) er stipendiat ved Institutt for nevromedisin, Det medisinske fakultet, Norges teknisk-naturvitenskapelige universitet.

Forfatter har fylt ut ICMJE-skjemaet og oppgir ingen interessekonflikter.

Thea Forr (f. 1985) er turnuslege på Lillehammer.

Forfatter har fylt ut ICMJE-skjemaet og oppgir ingen interessekonflikter.

Ahmad Al-Fattal (f.1968) er overlege og spesialist i geriatri og i indremedisin. Han er faglig rådgiver for geriatri ved Medisinsk klinikk,

Sykehuset Telemark.

Forfatter har fylt ut ICMJE-skjemaet og oppgir ingen interessekonflikter.

Cathrine de Groot (f. 1969) er fagutviklingsterapeut M.Sc. og prosjektleder for fallforebygging ved Sykehuset Telemark.

Forfatter har fylt ut ICMJE-skjemaet og oppgir ingen interessekonflikter.

Greger Lønne (f. 1964) er ph.d., spesialist i ortopedisk kirurgi og overlege ved Sykehuset Innlandet, Lillehammer.

Forfatter har fylt ut ICMJE-skjemaet og oppgir ingen interessekonflikter. 
Edith Roth Gjevjon er førsteamanuensis ved Høyskolen Diakonova.

Forfatter har fylt ut ICMJE-skjemaet og oppgir ingen interessekonflikter.

Geir V. Berg er forskningsveileder/rådgiver ved Sykehuset Innlandet, Lillehammer og førsteamanuensis ved Høgskolen på Gjøvik.

Forfatter har fylt ut ICMJE-skjemaet og oppgir ingen interessekonflikter.

Sverre Bergh (f. 1973) er forskningsleder ved Alderspsykiatrisk forskningssenter, Sykehuset Innlandet, Sanderud.

Forfatter har fylt ut ICMJE-skjemaet og oppgir ingen interessekonflikter.

\section{Litteratur}

1. Inouye SK, Westendorp RGJ, Saczynski JS. Delirium in elderly people. Lancet 2014; 383: 911-22.

2. American Psychiatric Association. Diagnostic and statistical manual of mental disorders. 5. utg. Arlington, VA: American Psychiatric Association, 2013.

3. Witlox J, Eurelings LS, de Jonghe JF et al. Delirium in elderly patients and the risk of postdischarge mortality, institutionalization, and dementia: a meta-analysis. JAMA 2010; 304 443-51.

4. Neerland BE, Watne LO, Wyller TB. Delirium hos eldre pasienter. Tidsskr Nor Legeforen 2013; 133 1596-600.

5. 4AT - Rapid assement test for Delirium. http://the4at.com (7.12. 2015).

6. Bellelli G, Morandi A, Davis DH et al. Validation of the 4AT, a new instrument for rapid delirium screening: a study in 234 hospitalised older people. Age Ageing 2014; 43: 496-502.
7. Norsk geriatrisk forening. Tester og registreringsskjemaer. http://legeforeningen.no/Fagmed/ Norsk-geriatrisk-forening/

Geriatrisk-test--og-undervisningsmateriel/ tester-og-registreringsskjemaer/ (7.12. 2015).

Mottatt 11.12. 2015 og godkjent 25.1. 2016. Redaktør: Kaveh Halland Rashidi.

Publisert først på nett. 